\title{
IUCN 14th General Assembly at
}

\section{Ashkhabad}

The most important decision taken at the IUCN 14th General Assembly at Ashkhabad, Turkmeniya, in September/October, was the adoption of the World Conservation Strategy, the title of which exactly describes its purpose and scope. The strategy will govern the Union's policy and action for the next three years - until the next General Assembly, intended to be in New Zealand. The research for this exhaustive document ( 96 pages) has been financed by UNEP (United Nations Environment Programme) and WWF. Now, for the first time, IUCN has its guidelines and priorities documented on a world scale.

Another most important decision was that much higher priority and financial support should be given to the Union's six Commissions. On this agreement was unanimous. A full-time executive officer for each commission at IUCN headquarters in Switzerland was considered an absolute minimum, plus some financial aid both for Chairmen's expenses and to enable commission members to meet - a quite vital provision, as the commissions are composed entirely of voluntary experts and specialists drawn from all over the world. The six commissions are concerned with national parks, environment, education, law, ecology, and endangered species; the last, rather oddly named the Survival Service Commission (SSC), is the one that has been most successful hitherto in getting the sort of help now envisaged for all, and also the one that most concerns FPS. Its chairman is Sir Peter Scott, who was re-elected; Richard Fitter is Chairman of the Steering Committee and of the Arabian Oryx Group, John Burton chairs TRAFFIC (also an SSC group) and the Editor of Oryx is the FPS representative. For the past year SSC and also CNPPA (national parks), has had a full-time Executive Officer thanks to the generosity of the US and Canadian Governments, and the West German Government has given considerable support to the Commission on Environmental Policy, Law and Administration, but the education, ecology and environment commissions have had little support. The new emphasis on and recognition of the importance of the commissions is a considerable policy change, and the results will be watched with interest.

The Ashkhabad meeting saw the retirement of the President of the last six years, Dr Donald Kuenen, of the Netherlands, whose stalwart services were spoken of with warm appreciation, and the appointment in his place of $\mathrm{Dr}$ Mohammed Kassas of Egypt, Professor of Plant Ecology at Cairo University and joint winner of the 1978 International Pahlavi Environmental Prize. Dr Kassas is the first IUCN President to come from a country outside western Europe or the USA.

Three Vice-Presidents were elected: Robert Boote CVO, Director of the UK Nature Conservancy Council; Dr A. M. Borodin (USSR), and Russell E. Train (USA); Dr Don McMichael of Australia succeeds Mr Boote as Treasurer.

Thirteen Honorary Members of IUCN were elected in recognition of their major contribution to the Union's work since its foundation in 1948: Miss Phyllis Barclay-Smith CBE (UK); Dr Enrique Beltran (Mexico); Dr Boonsong Lekagul (Thailand); Dr Kai Curry-Lindahl (Sweden); Professor François Bourlière (France); Jean-Paul Harroy (Belgium); Professor Roger Heim (France); Max Nicholson CB, CVO (UK); Fred Packard (USA); William E. 
Phelps Jr (Venezuela); Dr Duncan Poore (UK); Charles van der Elst (Belgium); Dr E. Barton Worthington CBE (UK).

Delegates at this Assembly had a rush to the head on resolutions and had to have a late-night sitting to get through them; 35 were passed, a large proportion concerned with marine conservation. One resolution urged the UK Government to suspend any cull of grey seals on Scottish islands until adequate data on their impact on fish stocks was available, and this was transmitted to the Secretary of State for Scotland by the FPS Hon. Secretary, Richard Fitter, on his return from Ashkhabad, when he took part in a deputation led by $\mathrm{Mr}$ Jo Grimond. On whales IUCN continues to call for a moratorium on commercial whaling until certain requirements are met, notably the supply of accurate and adequate data, and urges members to 'work vigorously' to ensure that they are met.

Another resolution urged all marine fishing nations to take the necessary steps to eliminate 'incidental takes', eg dolphins and turtles caught in fishing nets. Effective governmental protection was demanded for sea turtles in Mexico, black rhino in African countries, (believed to be seriously threatened), Iriomote Island and the Iriomote cat in Japan (full protection for underdeveloped areas on the island and a permanent ecological research station were called for), and Abbott's booby on Christmas Island (Indian Ocean), where phosphate mining has destroyed a major part of the breeding area (the only known site) and now threatens to destroy the last good breeding area-a case of sheer greed; the Australian Government is urged to establish a national park and reserves. On the pet trade, a resolution put forward by FPS recommends that 'all nations prohibit or restrict as appropriate the entry of wild-caught animals into the pet trade'.

On deep sea mining a resolution urged the vital need for preliminary research and, in effect, environmental impact statements. Another pointed to the importance of ocean trenches as centres of endemism containing many undescribed species and unusual habitats, urged the end of dumping in these trenches and the need for some of them to be given sanctuary status.

On oil pollution in the sea, governments are urged to conclude an interim agreement on safety standards for oil tankers, to be enforced by heavy penalties. The need for a North Sea atlas as a cooperative project was also urged on all the governments concerned. In the Antarctic Ocean a long resolution urged that the nations concerned accede to the appropriate treaties, that the taking of krill be strictly regulated with an independent observer system to enforce regulations, that Specially Protected Areas be created, and also urged the need for an International Decade of Southern Ocean Research.

The final resolution was one of 'warmest appreciation' to the Governments of Turkmen SSR and the USSR and the citizens of Ashkhabad for their hospitality and of 'highest appreciation' to the organising committee. The hospitality and warm welcome the delegates received and the excellent organisation were matters of general comment, coupled with the excellent work done in the meetings, for which much credit was due to the thorough preparatory work done by the IUCN staff and especially the Director General, Dr David Munro, to whom a warm tribute was paid. This Assembly was widely felt to be one of the pleasantest and most productive yet.

M.F. 